\title{
The Warriors of the Frontier: the Osavul Office (Aide-De-Camp) in the Military Structure of Ukrainian Cossack and Turkic Armies
}

\author{
Oleksii Sokyrko' [0]
}

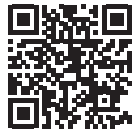

'Corresponding author/Sorumlu yazar: Oleksii Sokyrko (Assoc. Prof.),

Taras Shevchenko National University of Kyiv, History Department, Kyiv, Ukraine. E-posta: sag@univ.kiev.ua ORCID: 0000-0003-3841-9782

Submitted/Başvuru: 13.09.2020 Revision Requested/Revizyon Talebi: 00.00 .0000

Last Revision Received/Son Revizyon: 00.00 .0000

Accepted/Kabul: 26.01.2021

Citation/Atıf: Mykhailutsa, Mykola and Niculcea, Igor, "The Southern Bug Dnister Interfluve During World War II: Administrative Organization, Staffing and Statistics", Güneydoğu Avrupa Araştırmaları Dergisi, 35 (2020), s. 119-136.

https://doi.org/10.26650/gaad.794397

\begin{abstract}
The article is dedicated to the study of the historical roots and the process of evolution of the institution of osavul in the Cossack Army and in the government of Hetmanate (Hetmanshchyna, the Ukrainian Cossack State). The osavul office appeared in the early Cossack military structure as a result of its relations with nomadic societies. The comparison between a cossack osavul and a corresponding officer of a Turkic army reveals a lot of common functions: both could be responsible for mobilization, commanding of field, camping and management of quartering, combat intelligence and military discipline. The other factors that affect the state and the functions of a cossack osavul included the structure of the Crown Troops of the Polish-Lithuanian Commonwealth (Rzeczpospolita) and the system of patron-client relations formed on the frontier during the sixteenth and the seventeenth centuries. In the Hetmanate, these basic functions were supplemented by administrative assistance to the hetman, and by some judicial and diplomatic duties.
\end{abstract}

Keywords: Cossack Hetmanate, Aide-de-Camp, Registered Cossacks, Cossack Officials, Free-lanced Troops, Nomadic Armies 
The formation of the Cossack society began in late fifteenth and early sixteenth centuries on the frontier of the Tatar steppe (Dyke Pole Wild Fields), therefore this process has been under strong Eastern nomadic influences from the very early stages. Since the early Cossack communities were ethnically and culturally mixed between Turks and Slavs, and their living depended on the specific way of nomadic warfare, these Eastern influences primarily affected the military organization. ${ }^{1}$ Osavul was one of the most important and influential offices in Zaporozhian Host (Zaporozhian Sich) and later in the Registered Cossack Army. Osavuls accumulated the biggest amount of proper military functions compared to the other senior officers (koshovyi otamans, hetmans, obozni (quartermasters), pysari (chancellors), suddi (judges), polkovnyky (colonels) etc.).

The osavul office was not popular among the historians who study the Hetmanate and the Cossack Army because it was ranked quite low in the hierarchy of General Staff (Heneralna Starshyna) and gained political functions at the late stages of its existence ${ }^{2}$. Today the relevant research are limited to the biographies of several General Osavuls, and general studies of the office's functions and their evolution in the late periods of the Hetmanate history ${ }^{3}$.

A productive method to study the functions and the nature of osavul in the Cossack Army is to analyze it by comparing with the relevant offices in Turkish and other Eastern nomadic

1 More about nomad's military organization see: Hrybovs'kyj Vladyslav, “Vijs'kova systema Nohajs'koi ordy ta yiyi restytuty u prychornomors'kyh nohajciv", Humanitarnyj zhurnal, 2012, № 2-3, p. 81-84; Khazanov Anatolii, "The Eurasion Steppe Nomads in World Military History", Nomad Aristocrats in a World of Empires, Ed.by J.Paul, Weisbaden, 2013, p.187-207; Manz Beatrice Forbes, "Nomads and Regional Armies in the Middle East", Nomadic Military Power in Iran and Adjacent Areas in the Islamic Period /Ed. by K.Franz and W.Holzwarth, Nomaden und Sesshafte 17. Wiesbaden: Reichert, 2013, p. 1-27; Paul Jurgen, "The State and the Military - a Nomadic Perspective", Militär und Staatlichkeit. Beiträge des Kolloquiums am 29. und 30.04.2002, Hg.I. Schneider, Halle, 2003 (Orientwissenschaftliche Hefte 12; Mitteilungen des SFB „Differenz und Integration” 5), p. 25-68.

2 Apanovych Olena, Zbrojni syly Ukrainy pershoyi polovyny XVIII st., Kyiv, 1969, p. 62-67; Babkova Nataliya, “Instytut osavuliv v ukrayins'komu kozactvi XVI - XVIII st.", Hileya: Naukovyj visnyk, 2015, v.96, p. 11-14; Horobec'Viktor, Politychnyj ustrij ukrayins'kyh zemel' druhoyi polovyny XVII - XVIII stolit', Kyiv, 2000, p. 38-39; Dyadychenko Vadym, Narysy suspil'no-politychnoi istoriyi Livoberezhnoi Ukrayiny kincya XVII - pochatku XVIII st., Kyiv, 1959, p. 186-189; eiusdem. "Ukraynskoe kazackoe vojsko v konce XVII - nachale XVIII vv.", Poltava: K 250-letyyu Poltavskoho srazhenyya, Moskva, 1959, p .246-268; Slabchenko Mikhail, Malorusskij polk v admynystrativnom otnoshenii. Istoriko-yuridicheskij ocherk, Odessa, 1909, p. 81-84; Putro Oleksii, “Ukrayins'ke kozac'ke vijs'ko", Kyivs'ka starovyna, 1997, № 6, p. 4-5, 11; Sokyrko Oleksii, “Ukrayins'ke vijs'ko Kozac'koyi doby", Istoriya ukrayins'koho vijs'ka, Kharkiv, 2016, p. 203-234; Zaruba Viktor, Ukrayins'ke kozac'ke vijs'ko v rosijs'ko-turec'kyh vijnah ostann'oyi chverti XVII stolittya, Dnipropetrovs'k, 2003, p. 84-131.

3 Kazimirov Dmytro, “Maetnosti chernihivs'koho polkovoho osavula Vasylia Pavlovs'koho u Mens'kij sotni”, Siveryans'kyj litopys, 2016, № 1, p. 97-106; Medveds'kyj Vladyslav, “Heneral'nyj osavul Yakiv Yakubovych ta joho vijskova diyal'nist'”, Materialy XII mizhnarodnoyi mizhdyscyplinarnoyi naukovoyi konferenciyi studentiv, aspirantiv ta molodyx vchenyh «Shevchenkivs “ka vesna 2015: Istoriya», Kyiv, 2015, p. 290-293; eiusdem. “Diyal'nist' uryadu heneral'noho osavula za het'mana Bohdana Khmel'nyc'koho", Dni nauky istorychnoho fakul'tetu, prysvyacheni 180-richchyu zasnuvannya Kyyivs'koho universytetu, Kyiv, 2014, p.64-68; eiusdem. "Instytut heneral'nyh osavuliv u Het'manshhyni v seredyni XVII - kinci XVIII st.", Materialy XII mizhnarodnoyi mizhdyscyplinarnoyi naukovoyi konferenciyi studentiv, aspirantiv ta molodyx vchenyx "Shevchenkivs“ka vesna 2014: Istoriya», Kyiv, 2014, p. 104-107; Okynshevych Lev, "Heneral'na starshyna na Livoberezhnij Ukraini XVII - XVIII vv.", Praci komisii dlia vyuchuvannia zahidno-rus'koho ta vkrayins'koho prava, Kyiv, 1926, v.2, p. 139-152. 
armies. The great influence of Crimean Khanate and the Ottoman Empire on the military organization and government of the Hetmanate and Polish-Lithuanian Commonwealth in general is well known among Ukrainian and Polish historians. Therefore, the comparative analyses used in this study shall help to discover some essential traits of the military institutions which could not be deciphered directly from the currently available sources. ${ }^{4}$

The administrative system and the hierarchical structure of the Cossack Army started its formation in the mid late sixteenth century at Zaporozhian Sich. The Registered Cossack Army organized in Polish-Lithuanian Commonwealth between 1568 and 1572 was based on the traditions established there. Such documents as the Royal decrees, the Sejm (Parliament) edicts and the Cossack Army registers show that osavuls were second in rank to colonels (polkovnyk), and were probably their direct subordinates ${ }^{5}$.

Most probably, a cossack osavul (as well, as otaman, oboznyi (quartermaster) and the other basic positions) has its origins in the earliest military structures formed by the first warriors of the steppe frontier who borrowed a lot from the Turkic nomads in their organization and hierarchy ${ }^{6}$. The office of osavul definitely has Eastern roots - it is an element of the military structure of many nomadic people of Eurasia. For the Mongols zahul (zasul or zahuul) was the name of the Khan's hunting administrator responsible for managing the order of lines and the distance between groups of hunters. Each hunting line had two zahuls, one in front and one in back. ${ }^{7}$ Researchers of nomadic cultures derive this term from the word that means "manager" or "aide-de-camp". The root of the word "jasa" comes from Turkish word that means "to align", "to organize", and "-ul" at the end of the word to verbalize a military term.

4 Dziubiński Andrzej, “Poturczeńcy polscy. Przyczynek do historii nawróceń na islam w XVI-XVIII w.”, Kwartalnik Historyczny, 1995, Nr.102/1, p. 19-37; Gliwa Andrzej, "O woskowości tatarskiej w epoce nowożytnej i oddziaływaniu koczowników na osiadłe spoleczności Rzeczypospolitej", Spoleczeństwo Staropolskie, 2015, t.IV, s.89-133; Halenko Oleksandr, "Konstytucijni idei Pylypa Orlyka z perspektyvy stepovyh vytokiv politychnoi tradycii ukrayins'koho kozactva", Pylyp Orlyk: zhyttia, polityka, teksty: Materialy Mizhnarodnoi naukovoi konferencii «Ad fontes» do 300-richchya Benders koyi konstytuciyi 1710 r., Kyiv, 2001, p. 224-233; eiusdem. "Luk ta rushnycia v lycars'kij symvolici ukrayins'koho kozactva: paradoksy kozac'koyi ideolohii ta problema shidnoho vplyvu", Mediaevalia Ucrainica: Mental'nis't ta istoria idej, Kyiv, 1998, t.V, p. 93-110; Kołodziejczyk Dariusz, "Permeable Frontiers: Contacts between Polish and Turkish-Tatar Elites in Early Modern Era", Foreign Drums Beating. Transnational Experiences in Early Modern Europe, Ed.by B. Forsen and M. Hakkarainen, Helsinki, 2017, p. 153-168; Pylypenko Volodymyr, "Skhidne oblychchya kozaka Mamaya", Visnyk Chernihivs'koho nacional'noho pedahohichnoho universytetu. Seriya: Istorychni nauky, 2015, v.134, p. 18-23.

5 Cherkas Borys, “Kozac'ke vijs'ko do seredyny XVII st.", Istoriya ukrayins'koho kozactva: Narysy v 2 tt., Kyiv, 2006, t.l, p. 472-474; Serhijchuk Volodymyr, Armiya Bohdana Khmel'nyc'koho, Kyiv, 1996, p. 55, 64-65; Yavornyc'kyj Dmytro, Istoriya zaporiz'kyh kozakiv /Per.z ros.l. Svarnyka, L'viv: Svit, 1990, t.I, p. 138, 142-143.

6 Hrybovs'kyj Vladyslav, "Zaporoz'ke kozactvo i cholovichi soyuzy Kavkazu ta Central'noyi Aziyi v komparatyvnij perspektyvi", Hileya: naukovyj visnyk, 2011, v.52, p. 116-130; eiusdem. "Socyal'naia typolohia kazach'yh soobshestv", Kazachestvo v tyurkskom y slavyanskom myrah: Kollektyvnaya monohrafyya, Instytut arheolohii im.A.Halikova AN RT, Kazan', 2018, p.94-172; Sen'Dmitrij, “Kazach'e naselenie Krymskoho hanstva: maloizuchennye aspekty rasselenija (konec XVII - XVIII vv.)", Vspomohatel'nye istorycheskye dyscyplyny $v$ sovremennom nauchnom znanii: Materyaly XXXI Mezhdunarodnoj nauchnoj konferencii. Moskva, 12-14 aprelia 2018 h., Moskva: Institut vseobshhej istorii RAN, 2018, p. 327-330.

7 Kushkumbaev Aibolat, Voennoe delo kazakhov v XVII - XVIII vekah, Almaty: Dajk Press, 2001, p. 23. 
The term has many variants in different Turkic languages: iasaul, jasauil, jasaul; all used to define an army officer responsible for the aligning warriors for an attack, parade or hunting, and managing sitting order of the guests at ceremonial receptions and banquets.

As Kazakh historian Aibolat Kushumbaiev states, this office was initially created for the needs of Turkic and Mongolian collective hunts in the steppe, and always played a notable role in the process of inner integration of a nomadic society. Later, the sphere of jasovul's responsibilities was broadened by military functions, namely the management of the army formations movement and the orders of battle. ${ }^{8}$ There is another peculiar position, -probably an extension of the jasovul office- a special judge who controls the distribution of hunted prey called zasahul. ${ }^{9}$

It is important to note that the military and administrative structure of the PolishLithuanian Commonwealth, which is another essential example for the organization of the Cossack Army, did not have direct equivalents of osavul. Although some similarities could be seen between osavuls and guards (strażnyky) who could take different places in hierarchy, they had roughly the same circle of functions: combating intelligence command, guard posts and warding management, etc. In seventeenth century, the Crown Guard and the Lithuanian Guard (praefectus excubiarum seu vigilirum) were listed among the senior officers of the Hetman's Staff immediately after the Crown Hetman and the Lithuanian Hetman, even though their functions were limited to marching management, supervision over vanguard (straża przednia), wards, and watches in quartering posts. This position was assigned by the hetman, yet apparently it derived not from a military office, but from a court one. It is demonstrated by the fact that the guards appeared in the army only when it was led by the King, while the Grand Crown Hetman had a Field Hetman performing the guard's duties. ${ }^{10}$

The field guard already existed in the seventeenth century. At first, he was responsible for the defense of the Eastern borders (between Polish-Lithuanian Commonwealth, and Moscow and Crimean Khanate). In rank, he was a commander of the mercenary formations protecting the border of steppe (called obrona potoczna - "the current guard"), he was literally a guard. Later, these functions were transferred to the Grand Crown Guard. ${ }^{11}$

The mercenary formations of the Polish-Lithuanian Army (wojsko kwarciane) and the nobleman levy of szlachta (pospolite ruszenie) had their own variants of the guard office: for the mercenary it was the regimental guard, and for the latter it had palatinate and district guards. All of those had roughly the same functions - they managed the supervision in the field and the warding in quartering. The list of provincial offices included guards, but those were

8 Kushkumbaev Aibolat, Instytut oblavnykh oxot i voennoe delo kochevnikov Central'noj Azii. Sravnytel'noistorycheskoe issledovanie, Kokshetau, 2009, p.34-35, 57-58, 60.

9 Ibid, p.59.

10 Góralski Zbigniew, Encyklopedia urzędów i godności w dawnej Polsce, Warszawa, 2000, S.153.

11 lbid. S.152. 
out of the traditional nomenclature (with exception of the Lithuanian Guard called górniczy), which signifies their indistinct and unstable position. ${ }^{12}$ So, it is evident that in the Polish and Lithuanian Armies, the functions of army management and the organization in the field were carried out by the guards, they were distributed among a bunch of different types of guards with different status and level of responsibility. This makes an additional argument for the statement that the office of Cossack osavul was closer to the nomadic equivalents, not to the Polish or Lithuanian guards.

The organization of the Cossack Army went through a number of essential changes as the result of Bohdan Khmelnytskyi Uprising it was after 1648 when the Cossack autonomy was established inside the Polish-Lithuanian Commonwealth and the Cossacks gained their own army independent from the authority of the King, the Sejm or the Crown Hetman.

Then the Cossack hetman became the official commander in chief and got the right to convert and disband the troops and to command the operations. There appeared two general osavuls in hetman's direct subordination; besides that, there was an osavul for each regiment (polk) and detachment (sotnia). The sphere of their responsibility included rosters and records kept for their divisions, registration of the troops for a new campaign, management of salaries and food supplies. Their most important function was to organize mobilization to each regiment and detachment. So, we see that the role of osavuls in the administration of the modernized Cossack Army had quite a limited functional sphere; for instance, the artillery had their own senior manager, namely the general quartermaster (heneralnyi oboznyi).

Ukrainian historian Lev Okynshevych states that the office of general osavul was among the so called "second stage seniors" (along with heneralnyi bunchuzhnyi and heneralnyi khorunzhyi) in the traditional hierarchy of General Staff (heneralna starshyna) of the Cossack Army, which means its authority and political role was less than the general quartermaster, general judge or general secretary. ${ }^{13}$ Yet, it is more probable that such a hierarchy was only established in the Hetmanate; therefore, before the middle of seventeenth century, the osavuls had had higher status. There are some arguments about this theory, for example, in the Treaty of Kurukove, (1625) osavuls appear on the list immediately after the Hetman, and their salary is higher than that of quartermasters and secretaries. ${ }^{14}$

The process of the inner hierarchy of Cossack senior officers' formation that took place in eighteenth century still left the rank of osavul uncertain. The edition of The Order of Military Ranks and Offices of The Minor Russia (Malorossia) ${ }^{15}$ in 1742 positioned osavuls in the third class along with heneralnyi bunchuzhnyi and heneralnyi khorunzhyi. However, in the edition

12 Ibid.

13 Okynshevych Lev, “Heneral'na starshyna na Livoberezhnij Ukraini XVII - XVIII vv.", p. 140.

14 Arkhiv Yugo-Zapadnoj Rossii, Kiev, 1872, Ch.1, t.V, p. 288.

15 "Степенный Малороссійскихъ воинского званія чиновъ порядок" - an official nomenclature of the Cossack officers. 
of the same document in 1756, they were listed among the General Staff in the first class. ${ }^{16}$ These two editions show the same shift for the regimental osavuls - they moved from the seventh to the fifth class (below regimental judges and secretaries, but above sotnyks (the sotnia's commanders) - and the Sotnia Osavuls moved from the tenth to the eighth class. ${ }^{17}$

The osavul office was not very popular and desirable for a senior officer, especially in terms of a political career. Lev Okynshevych rightfully noted that most of the general seniors, such as quartermasters, secretaries or judges, skipped the stage of a colonel, while for osavuls this rank was usually the greatest career achievement. ${ }^{18}$ The scholars explain this tendency by the instability and inferiority of this office and its jurisdiction.

Yet, it seems that this informal hierarchy was also unstable. Besides, another motive could be significant here. The campaigns were frequent, especially in the so-called Ruin Period (Time of Troubles - 1657-1687). At that time, the army management required spending most of the time in field, which meant severe living conditions and constant threats, so not every senior officer was capable of such a job or willing to do it. Therefore, in the second half of seventeenth century most of the osavuls were coming from the militarized peasant leaders or the former Zaporozhian chiefs. This is evident from their names, or rather nicknames, found in the sources, such as Vas'ko, Demko, Shulyka (lit. "Hawk"), etc. Due to the intensity of the military activity, it was quite natural that the real field commanders and managers were rising to the respective official position. Those were mostly the people of low social origins for whom the rank of a colonel was attractive and respected enough to make a be a sufficient prize for the good service - it worked as a kind of honorary pension or sinecure.

The military and political turbulence of the Ruin Period caused the increase of osavuls' importance and influence. They acquired the role of the supporters of hetmans' and colonels' authority. In 1664, Hetman Teteria issued a project of a new administrative system for Hetmanate which raised the size of the regimental osavul's rank estates (ranhovi majetnosti) to that of a colonel and added the share of their income sources. ${ }^{19}$ The list of the officers was presented at the secret meeting in January 1671 , including all colonels, regimental osavuls and sotnyks, but hardly any quartermasters, judges or secretaries. ${ }^{20}$ There was another aim why many osavuls made good starts and/or changed political careers: due to frequent campaigns in which their

16 Prava, za iakymy sudyt'sia malorosijs'kyj narod. 1743, Kyiv, 1997, p.547; Rossyjskyj Gosudarstvennyi Arkhiv Drevnikh Aktov (Moscow, Russia), Fond 13, opys 1, delo 40, list $13 \mathrm{v}$.

17 Prava, za iakymy sudyt'sia malorosijs'kyj narod. 1743, Kyiv, 1997, p.547; Rossyjskyj Gosudarstvennyi Arkhiv Drevnikh Aktov (Moscow, Russia), Fond 13, opys 1, delo 40, list 14 - $14 \mathrm{v}$.

18 Okynshevych Lev, “Heneral'na starshyna na Livoberezhnij Ukraini XVII - XVIII vv.", p. 140-141.

19 Horobec'Viktor. “Kozac'kyj Het'manat u social'nij strukturi Rechi Pospolytoi: proekt ustroyevoyi modeli het'mana Pavla Teteri z roku 1664", Moloda naciya, 2000, № 1, p. 40-61.

20 Horobec'Viktor, "Vsyakie polkovye uryady". Polkova starshyna Het'manatu yak vladnyj instytut i socialna hrupa", Socium. Al'manah social'noyi istoriyi, 2017, v.13-14, p. 15; Okynshevych Lev, "Central'ni ustanovy Ukrainy-Het'manshyny XVII - XVIII st. Ch.2: Rada starshyn", Praci komisii dlia vyuchuvannia zahidno-rus'koho ta vkrayins'koho prava, Kyiv, 1930, v.8, p. 294-296. 
rotations was fast; they preserved a constant contact with the soldiers which could make them widely popular and provide an advantageous image of a "worthy warrior" (“заслужоного у войску"). Hence, in that time the office of general osavul was rather attractive for colonels; there were even two hetmans who started as osavuls; Petro Doroshenko (1665-1676) and Ivan Mazepa (1687-1709).

At the end of seventeenth century when the usual circle of military administrative functions of general osavuls were supplemented with a number of civil tasks, this office became popular among the sons of the Cossack colonels and sotnyks. Consequently, the office of regimental osavul became more acceptable for the junior officers and the qualified part of troopers (the chiefs of the sotnia level and secretaries). The latter variants of osavuls tended to accept their career with the sotnyk position, a rather quiet and profitable one. In both cases, the osavul office was considered convenient either as a good start of a military career, or as a good conclusion.

As a rule, general osavul and regimental osavul were double offices. There was such a tradition long before the Khmelnytsykyi Uprising. In the middle of seventeenth century in Hetmanate, it became habitual to have two persons at each of these positions. ${ }^{21}$ Most probably this practice originated from the nomadic laws. In the golden age of the Genghis Empire (Thirteenth - fourteenth centuries), both its civil state administration and military structure were separated by two wings. After the Empire's disintegration, this system was preserved almost in all of its former parts. For example, the official decrees (jarlyks) issued by Crimean Khan began with the traditional Genghis formula: "The Right and The Left Hands of The Great Orda". ${ }^{22}$ This division of Crimean Orda is the possible reason for Crimean Khan to have two sultans as his deputies - kalgay sultan and nureddin sultan. ${ }^{23}$

Since the Hetmanate had a big territory divided in two by the river Dnipro, the need of two osavuls was rather natural here. Apparently, this separation between the Left Bank and the Right Bank existed informally long before the Cossack State's official division in 1663. An argument for that may be found in the Pereiaslav Articles signed in 1659, where Article 11 prescribed that hetman should have "a judge, a jasaul/osavul and a secretary at each of the sides of Dnipro". ${ }^{24}$

It looks like there was an inner hierarchy and a specific distribution of functions between the two general osavuls (Prof. Okynshevych used to identify the second osavul as minor in rank and confuse it with the sub-osavul (pidosavulii) even though such an office appeared in

21 Akty, otnosiashiesia k istorii Yugo-Zapadnoj Rossii (AYZR), Sankt-Peterburg 1863, t. IV, p. 68.

22 Kushkumbaev Aibolat, „Kryl'evaja model' v voenno-politycheskoj orhanizacii imperii Dzhuchidov”, Voennoe delo ulusa Dzhuchi i ego naslednikov: Sbornik nauchnykh statej, otv.red.A.Kushkumbaev, Astana: Foliant, 2012, p.116-119, 154.

23 Hrybovs'kyj Vladyslav, "Vijs'kova systema Nohajs'koi ordy ta yiyi restytuty u prychornomors'kyh nohajciv”, Humanitarnyj zhurnal, 2012, №2-3, p.77.

24 Istochniki malorossyjskoj istorii, Moskva, 1855, t.l, p.5. 
the eighteenth century's documents on its $\left.0 \mathrm{wn}^{25}\right)$. This difference is evident from the sums of salary: at the 1672 year's council (rada), Prince Romodanowsky gave "to the osavuls: to Ivan Lysenko forty sables [0.S.], sixty rubles, to Lesko Cherniak forty sables, thirty rubles". ${ }^{26}$ However, in the eighteenth century, both general osavuls received an equal salary. The register of 1756 gives a sum of four hundreds rubles per year; ${ }^{27}$ the inequality in the size of their service estates was removed as well. ${ }^{28}$

Due to the lack of sources, it is hard to find out whether the office of regimental osavul was also double or not. It is most likely that each regiment had two osavul positions, but one was a constant vacancy. ${ }^{29}$ Some sources from the late seventeenth century mention the office of sub-osavul (pidosavulii), for instance there was one in the Lubny regiment in 1691. Oleksandr Lazarevskyi argues that by the times of Hetman Ivan Skorodapskyi (1708-1722) this office turned into the second regimental osavul. ${ }^{30}$ However, Vadym Diadychenko who studied the regimental rosters and the lists of senior officers notes that sub-osavul appears to be a separate office, it has a stage lower than regimental osavul. ${ }^{31}$ We may suppose that the separation of functions and responsibilities of two osavuls were spontaneous; therefore, could differ from regiment to regiment. Viktor Horobets writes that one osavul was in charge of court and police, while the other managed proper military issues. ${ }^{32}$

The rotation of the osavuls went by a tradition rather than a formal law for a long time. Mykhailo Slabchenko stated that initially regimental osavuls were appointed by colonels, and it was not before the eighteenth century when this office became elective ${ }^{33}$. Yet, the historical facts disprove this theory by showing the cases in which osavuls were appointed directly by hetmans or colonels.

After 1715, the new regulations of the Cossack officers' rotation changed this process into an election between two or three candidates. The final decision over the candidate for a general osavul was delegated to the Tsar of Russia, and for a regimental osavul - to the hetman. Yet, this prescription was rarely practiced in reality. There were multiple other factors that

25 Lomykovskyj Vasylij, “Slovar' malorusskoj stariny”, Kievskaja Starina, 1894, №7, p.10.

26 AYZR, Sankt-Peterburg, 1877, t.IX, p. 952.

27 „Malorossijskie chiny i dolzhnosti i oklad ikh soderzhanija”, Kievskaja Starina, 1883, №6, p.384.

28 Nacional'na Biblioteka Ukrainy imeni V.Vernads'koho, Instytut Rukopysu (Kyiv, Ukraine) (NBUV. IR), Fond I, sprava 55827, k.25 v.

29 Horobec'Viktor, "Vsyakie polkovye uryady". Polkova starshyna Het'manatu yak vladnyj instytut i socialna hrupa”, Socium. Al'manah social'noyi istoriyi, 2017, v.13-14, p.13; Putro Oleksii, “Ukrayins'ke kozac'ke vijs'ko", Kyivs'ka starovyna, 1997, №6, p.11.

30 Heneral'noe sledstvie o maetnostyakh Nezhynskoho polka 1729-1730 hh., Chernyhov, 1901, p.74; Lazarevskij Aleksandr, Lokhvickij istoricheskij sbornik, Kiev, 1906, p.356.

31 Dyadychenko Vadym, Narysy suspil'no-politychnoi istoriyi Livoberezhnoi Ukrayiny kincya XVII - pochatku XVIII st., p.230.

32 Horobec'Viktor, “Vsyakie polkovye uryady”. Polkova starshyna Het'manatu yak vladnyj instytut i socialna hrupa”, p.20.

33 Slabchenko Mikhail, Malorusskij polk v admynystrativnom otnoshenii. Istoriko-yuridicheskij ocherk, Odessa, 1909, p.82. 
affected the election results, such as family relations, personal loyalties, protection offered by Russian imperial generals and governors, backstage agreements of hetmans and colonels.

Since the mid-eighteenth century, the sources testify a tendency to make vertical stageby-stage careers among the Cossack senior officers. Osavuls were not an exception, a random check of the lists of Cossack senior officers show that many of the regimental osavuls raised from the positions of sub-osavuls, regimental khorynzhyis (Flag-Bearer) or secretaries ${ }^{34}$; while the sotnia osavuls were mostly appointed from selected Registered Cossacks (vyborni kozaky) or Fellows of the Banner (znachkovi tovaryshy). ${ }^{35}$ In the former case it is seen as an example of an award for long-term service and participation in many operations, in the latter case. A typical career started for the sons of powerful parents. For instance, in the Chernihiv regiment five out of eleven sotnia osavuls had Cossack origins. So, there were two basic ways to the osavul position: a gradual vertical career (as in the first two examples) and a transfer from the "general offices" (as in the latter example). It is important to note that many historical sources make an impact on the "grade-by-grade" career type. It shows that the respective social and professional groups changed their view of a normal raise in rank: the formal regulations became a key factor in this process replacing the will of a ruler. This signifies the presence of an ordered community of officers with a strict inner structure and a formed bureaucratic system which is able to conduct independent elections on the level of a division.

The second half of seventeenth century was full of military campaigns. Therefore, the rotation of both general and regimental osavuls was rather rapid in this period, while during the comparatively peaceful times an osavul could hold his office for ten and more years.

The scholars still do not agree on the precise functions of an osavul. The circle of responsibilities and tasks performed by osavuls never gained any official regulations in the laws of Hetmanate, so they can only be deduced indirectly from the case studies. The picture appears to be scattered, which explains the conclusions about the office's specific inconsistency. However, the osavul's functions may be divided into two categories: military, administrative and judicial.

At this point, the historical nomadic roots of this office become significant. As have already been mentioned, in the steppe societies osavuls were in charge of an army's preparation for a campaign, mobilization, making lists and rosters, and alignment for a battle. Besides that, they took care of the commander's quarters defense, administration of the headquarters, organization of the reception for important visitors and ambassadors, hunting management, etc. The analogies between these functions and the sphere of the Cossack osavuls' power are pretty obvious.

34 NBUV. IR, Fond I, sprava 59060, k.347 v., 348 v; sprava 55453, k. 3 v., 4 3B.; sprava 55454, k. 36 v., 37 v.

35 NBUV. IR, Fond I, sprava.55453, k.27 v. - 29; sprava 55454, k. 55 v - 57v.; sprava 59060, k. 363 v. - 365 v. 
The researchers frequently note that the osavuls were performing the jobs of general and regimental councils' administrators, delegates and ambassadors, commanders of the Hetman's guards, and were conducting some confidential missions. ${ }^{36}$ The osavul's office had a close connection to the business of the Hetman. The Court Book of Poltava City Council gives a good illustration for this statement: in September 1678, the Regimental Osavul of Poltava Ivan Nasvit told how he "went against the adversary at the side of Mr. Prokop Levenets the Colonel of Poltava". ${ }^{37}$ No wonder that in the eighteenth century, the position of osavul was often compared to that of an adjutant, as Jean-Benoît Schérer did in his Annales de la petite Russie. ${ }^{38} \mathrm{~A}$ couple of decades later the similar connotations were introduced in "Specification of My Officers" in 1719 by Hetman Pylyp Orlyk, in which he mentioned two "general adjutants" - Hryhorii Hertsyk and Fedir Myrovych. ${ }^{39}$ The practice of having this position as double was legislated by the "Instruction for the General Osavuls" issued by Hetman Rozumovs'ky on December 5, 1763. It ordered that the two of them had to "alternate [in service] at the hetman's side for performing his current tasks and orders".40

There are many cases showing the diversity of such special tasks. One of the well-known examples is the case of the Kyiv Metropolitan's elections taking place in July 1685. The Suffragan of Kyiv Metropolitanate and the Archbishop of Chernihiv Lazar Baranovych - the most prospective candidate - made up a good excuse and did not come to the Election Council for being well aware that Hetman Ivan Samoilovych was not in favor of him. A great part of the senior clergy did the same, by doing this, they put the legitimacy of both the election procedure and the Council as such under threat. ${ }^{41}$ In the account of this situation, the Hetman sent a special delegation of four colonels (Vasyl Borkovs'ky of Chernihiv, Leontii Polubotok of Pereiaslav, Hryhorii Korovchenko of Kyiv and lakov Zhurakhovskyi of Nizhyn) and some minor officers headed by his personal attorney General Osavul Ivan Mazepa to the Election Council. Their mission was to make a solid support to the Hetman's protegee Archbishop of Lutsk and Ostroh Gedeon SviatopolkChetvertynskyi by their superiority over the clergy in power and number. ${ }^{42}$ This worked out exactly as Samoilovych expected, his delegates did not even have a need to intervene in the elections actively, their quantitative advantage made a sufficient guarantee on its own. ${ }^{43}$

Diplomatic missions made another common practice for general osavuls. For example, in December 1720, General Quartermaster (heneralnyi oboznyi) Vasyl Zhurakhovskyi headed the group of senior officers delegated to St. Petersburg "with a petition concerning the needs of Minor Russia (Malorossia)". 44

36 Okynshevych Lev, "Heneral'na starshyna na Livoberezhnij Ukraini XVII - XVIII vv.”, p.143.

37 Poltavs'ka mis'ka knyha (1668-1740), upor.V.Rynsevych, Kyiv, 2016, p.175.

38 Sherer Zhan-Benua, Litopys Malorosiyi, abo Istoriya kozakiv-zaporozhciv, per.z fr. V.Koptilov, Kyiv, 1994 , p.54.

39 Ukraina-Shveciya: Na perehrestyah istoriyi (XVII - XVIII st.). Kataloh mizhnarodnoyi vystavky, Kyiv, 2008 , p.136.

40 Okynshevych Lev, “Heneral'na starshyna na Livoberezhnij Ukraini XVII - XVIII vv.", p.142.

41 Arkhiv Yugo-Zapadnoj Rossii, Kiev, 1872, Ch.1, t.V, p.95-100.

42 Ibid, № XIV, p. 65-66.

43 Ibid, p.101-102.

44 Modzalevskyi Vadym, Malorossyjskyj rodoslovnik, Kiev, 1910, t.II, p.47 
Also osavuls often played a role of watchers (prystavs) for the foreign embassy missions, who managed their communication with a hetman, supplies and living costs, convoy and defense. For instance, the Russian ambassadors who came to Baturyn in 1691 were welcomed by General Osavul Andrii Hamalia. ${ }^{45}$ Supposedly, this kind of job discloses the most archaic functions of the osavul office taken directly from its progenitor Turkic jasovul, namely, the management of important events' organization and the relevant communication.

The osavuls had very close connections with hetmans and colonels, who entrusted them with extremely responsible, confidential, even delicate missions. They were responsible for the safety of rulers, royal courts and families, and embassies. This feature makes the osavul office similar to the ministerials (servi ministeriales) of the traditional Medieval Western Europe (close to a royal chamberlain, prévôt and the like). ${ }^{46}$ The process of formation of absolute monarchy as a type of government in Early Modern Western and Central Europe changed the system of ministerial as a social institute, so that the respective officials appeared in the middle between private and public services. Similarly, the position of osavul in the Hetmanate combined a formal status of public office and the functions lying in the private sphere; besides that at least until the first quarter of eighteenth century the promotion for an osavul depended exclusively on his personal loyalty to the hetman and to his private interests. It is hard to define whether this peculiarity of the office was taken from the Eastern traditions or developed out of the specific feudal relationships of a frontier society. It will not be wrong to assume that it could be an organic combination of these two.

On the list of the military duties of osavuls, the most important one was the mobilization and gathering of the Cossack troops. In the summer of 1657, the delegates from Moscow described how the Cossacks were prepared for a campaign, and one of them wrote: "and the osavuls started to drive out the Cossacks and ordered them to join the campaign". ${ }^{77}$ In June 1667, Muscovite soldier Trofim Korieniev watched the gathering of the Cossack Army on his way from Kyiv to Baturyn, moving through Krolevets he saw "how the osavuls alarm the Cossacks and tell them to join the army as soon as possible". 48

During the military campaigns, general osavuls could be in charge of an entire army (sometimes in the status of Acting Hhetman (nakaznyi hetman) or of a certain division performing a special operational level mission. For instance, in June 1651 Hetman Bohdan Khmelnytskyi had to leave the army near Berestechko, so he passed his command on to General Osavul Filon Jelalii. The latter is also known for taking part in reconnaissance and

45 Dyadychenko Vadym, Narysy suspil'no-politychnoi istoriyi Livoberezhnoi Ukrayiny kincya XVII - pochatku XVIII st., p.187.

46 Vlastnye instituty $i$ dolzhnosti v Evrope $v$ Srednie veka y rannee Novoe vremya, otv.red. T. Husarova, Moskva: KDU, 2011, p. 16, 26-27, 32-35, 60-70, 95-97, 131-137, 157-161, 189-192.

47 Dzherela z istoriyi Nacional'no-vyzvol'noyi vijny ukrayins'koho narodu 1648-1658 rr. /Upor.Yu.Mycyk, Kyiv, 2015, t.IV. 109.

48 NBUV. IR, Fond II, sprava 15422, k.67. 
planning for the battle of Zboriv in 1649.49 Another example can be found in the letter sent to Muscovite Tsar Oleksii Mykhailovych by Metropolitan loasaf of Corinth in 1651: "So the hetman gave his standard and mace to his osavul Demko ${ }^{50}$ and made him the second hetman [acting hetman - 0.S.]; and he sent him for Potocky and Kalynowsky, and with him he sent 60.000 Cossacks and 30.000 Nogais and Tatars". ${ }^{51}$ The same General Osavul Demko, on May 191651 , was ordered to Kamianets where he headed the united Cossack-Tatar troops together with Colonel Teteria. ${ }^{52}$ Also in May 1651, the Hetman sent three regiments to Bar: "Osavul Demko with Colonel Bohun, and with Iliash Bohach the Colonel of Chyhyryn, and 100.000 Cherkasses (Cossacks) with 30.000 Tatars, with them". 53

In August 1666, General Osavul Artem Martynovych ruled an army standing near Pishchane where seven colonels were under his command. ${ }^{54}$ In June 1667, Hetman Petro Doroshenko gave General Osavul Demian Pyliai the title of Acting Hetman and made him in charge of four regiments to seize Bila Tserkva. ${ }^{55}$ In September 1670, when Moscow demanded a division of Cossacks to suppress the Razin Riot, Hetman Demian Mnohohrishnyi ordered General Osavul Matvii Hvyntovka to lead it ("and under Matvii as the General Osavul was to be the former Colonel of Kyiv Kostiantyn Solonyna"). ${ }^{56}$

The General Osavuls of The Left-Bank, Hetmanate Ivan Lomykovskyi and Andrii Hamalia were regularly leading the divisions of Cossacks and mercenaries (okhotnyky) that fought off Tatars and attacked Turkish forts in the lower Dnipro during 1680s-90s. ${ }^{57}$ For example, in 1691, Hetman Mazepa wrote to Moscow that to oppose the Tatar raids "for the cases where military force is required General Osavul Andrii Hamalia is ordered to come with all the warriors he can gather from horodovi (Registered Cossacks) ${ }^{58}$ and mercenary regiments". ${ }^{59}$

Another traditional sphere of the osavuls' responsibility was intelligence. They organized the raids for gaining operational and tactical information (such as the enemy's number, goals and routes), managed the work of spies (shpyhy) inside the Polish-Lithuanian Commonwealth

49 Storozhenko Ivan, Bohdan Khmel'nyc'kyi i voyenne mystectvo u Vyzvol'nij vijni ukrayins'koho narodu seredyny XVII stolittya, Dnipropetrovs'k, 1996, kn.l, p. 245.

50 Kryvosheya Volodymyr. Kozac'ka elita Het'manshhyny, Kyiv, 2008, p.71.

51 AYZR, Sankt-Peterburg, 1861, t.III, p. 448.

52 Ibid, p. 451.

53 Ibid, p. 454.

54 AYZR, Sankt-Petersburg, 1869, t.VI, p. 148, 155.

55 Ibid, p. 192.

56 AYZR, Sankt-Peterburg, 1877, t.IX, p. 262.

57 Litopys Samovydcia, upor.J.Dzyra, Kyiv, 1971, p.153; Lysty Ivana Mazepy, upor. V.Stanislavs'kyj, Kyiv, 2010, t.Il, p. 344; Stanislavs'kii V'iacheslav, “Vijs'ko Zaporoz'ke u voyennomu protystoyanni j myrnyh perehovorah z Kryms'kym hanstvom u svitli novyh danyh z dokumentiv Ivana Mazepy 1691-1694 rr.", Het'man Ivan Mazepa: postat', otochennya, epoha. Zbirnyk naukovyh prac', Kyiv, 2008, p. 189.

58 Lit. "the town cossacks" - the people who served in the Cossack Army of Hetmanate, in contrast to the cossacks of Zaporizka Sich.

59 Dyadychenko Vadym, Narysy suspil'no-politychnoi istoriyi Livoberezhnoi Ukrayiny kincya XVII - pochatku XVIII st., p. 188. 
and Crimean Khanate, and performed multiple types of combating intelligence (this function was usual for the jasovuls in Mongol and Turkic armies as well). ${ }^{60}$ In August 1653, Hetman Khmelnytskyi "commanded the Osavul Demko with some Cossacks to leave for Bila Tserkva to capture a captive (jazyk - lit "a tongue")". ${ }^{61}$ In November 1687, just after the First Crimean Campaign, General Osavul Vuitsa Serbyn with a light cavalry unit made a special raid to the Kazykermen area to study how the Turks were fortifying this city. ${ }^{62}$

During the Russian-Turkish Wars of 1735-1739, it became a constant practice for general osavuls to command certain divisions of the Cossack Army. For instance, in the 1737 campaign General Osavul Fedir Lysenko headed the division of Cossacks from Starodub, Chernihiv and Kyiv regiments, and a regiment of mercenary cavalry (kompaniitsy). He was also the commander of the united division consisting of a Cossack Regular Company, a squad of zholdaks (the Hetman's Feet Guard), some mercenary (kompaniitsy) regiments and the Cossacks of Zaseims'kii Sotni (the seven Selected Cossac Companies from Nizhyn regiment). Judging from their disposition in the campaign, this division played a role of the Hetman's Army's operational reserve whose primary tasks were to repel the raids of Crimean Tatars and to provide safe river crossings for the main forces. ${ }^{63}$

Besides that, the functions of osavuls included the management of quartering, marches and ferriage, alignment for battles, inspections of the troops. It is interesting to note that, in the Turkic nomadic terminology the process of inspection is called jasal (jasau) or jasamak, and the name of the respective officer - jasavul - derives from it. ${ }^{64}$ The alignment was among the functions of Mongol and Turkic jasavuls as well. ${ }^{65}$

The emphasis on discipline and the elimination of deserters were not less important. And in the eighteenth century, the sphere of the osavuls' responsibility was complemented by another peculiar function - the Instruction issued by Hetman Kyrylo Rozumovsky on December 51763 placed them in charge of the Hetman's personal guard.

60 Kushkumbaev Aibolat, „Rol' peredovoho vojska v monhol'skoj taktycheskoj modeli vojny”, Vestnik Evrazyjskoho nacyonal'noho universyteta im.L.N.Humyleva, 2009, № 1(68), p. 130-131.

61 AYZR, Sankt-Peterburg, 1861, t.III, p. 497.

62 Kryvosheya Volodymyr, Kryvosheya Iryna, Kryvosheya Olena. Neuryadova starshyna Het'manshhyny, Kyiv: «Stylos», 2009, p. 335.

63 Sokyrko Oleksii, „Malorosijs'ka rehuliarna rota 1733-1739 rr.”, Kyivs’ka starovyna, 2010, № 5, p. 22.

64 Kushkumbaev Aibolat, „Smotr vojsk i znachenie pekhoty v voennoj orhanizacii Zolotoj Ordy”, Vestnik Kazakhskoho nacyonal'nogo universyteta im Al'-Faraby. Seria istoricheskaja, 2009, № 2(53), p.33.

65 Kushkumbaev Aibolat, „Takticheskoe postroenie vojsk v monhol'skuju epokhu”, Zolotoordynskaja cyvilizacia, 2014, №7, p. 255. 
Osavuls could be assigned to the distribution of salaries for Cossacks and mercenaries (okhotnyky). Before the eighteenth century there was no such office as treasurer (pidskarbii) and no fixed fiscal apparatus in the Hetmanate, so the function of salaries distribution was usually performed either by a General osavul or by a colonel. During 1701-1702, General Osavul Ivan Skoropadskyi arrived in the field several times to deliver money and clothes to the Cossack and mercenary regiments raiding in the Lieffland. ${ }^{66}$

To summarize all, the aforementioned functions of the osavul office in the military terms, they performed the functions of combat management primarily during the active warfare, while in the periods of peace the sphere of their responsibility was limited to inspection duty.

The development of the system of state governance in Hetmanate provoked the diversification of the sphere of osavuls' responsibility, mostly by supplementing the office's military functions with some judicial and administrative ones. Combining multiple functions of the totally unconnected fields was not an exceptional trait of the osavul, but a usual practice, which presents the Hetmanate as an underdeveloped state with no professional specialization of bureaucracy. At the same time, such a combination of functions is an illustration of a tricky system of private and public loyalties the osavuls operated in, a conflict between the tradition of personal service and the subordination to the commander (regimentum), and the need to improve the state governance system.

It was common for the osavuls to participate in the court sessions at the judicial institutions of different levels when the cases in consideration had a special importance for the superiors. For example, in 1690, the case connected to the Colonel of Pereiaslav Leontii Polubotok and the monk Solomon, which was a special personal concern for Hetman Ivan Mazepa, was investigated by General Osavul Andrii Hamalia, and Mazepa's personal secretary and confidant Zakharii Shyikevych. ${ }^{67}$ In 1707, General Osavul Ivan Lomykovsky and the Secretary of General (Supreme) Court Semen Savych worked over the conflict between Burgomaster (vijt) of Kyiv Dmytro Polotskyi and Acting Sotnyk of Kyiv Trofym Klymovych based on the longterm misunderstanding of the city magistrate and the sotnia administration over the latter's right to draft the citizens into the Cossack Army. ${ }^{68}$ And two famous scandalous corruption cases - the case in 1716 against Colonel of Poltava Ivan Cherniak and the case in 1718 against Colonel of Starodub Lukian Zhoravka - were managed by General Osavuls Stefan Butovych and Vasyl Zhurakhovskyi. ${ }^{69}$

At the level of a regiment, the situation was similar. Regimental osavuls frequently served as colonels' confidants in the issues of corruption cases, financial machinations, land

66 Dyadychenko Vadym, Narysy suspil'no-politychnoi istoriyi Livoberezhnoi Ukrayiny kincya XVII - pochatku XVIII st., p.189.

67 Ibid; Pavlenko Serhii, Otochennia het'mana Mazepy: soratnyky ta prybichnyky, Kyiv, 2004, p.99.

68 Andrievskij Aleksandr, „Kievskie smuty serediny proshlogo stoletia”, Kievskaja Starina,1886, №12, p.686.

69 Modzalevskyi Vadym, Malorossyjskyj rodoslovnik, Kiev, 1910, t.II, p.47. 
conflicts, and in the supervision of sotnias..$^{70}$ Colonels were in charge of local financial control; therefore, osavuls were also entrusted with such an initially irrelevant function as audition. For instance, in the Acts of the Starodub Sotnia Administration the Regimental Osavul of Starodub lakiv Zavadovskyi has no other mentions, but as "the regimental osavul who takes care of His Grace the Colonel of Starodub's market issues" or "the one sent to the market business". ${ }^{71}$ In 1727, an osavul and a khorunzhyi accompanied the Acting Colonel Pavlo Martos to the town of Romny "to audit the treasuries of the church and the sotnia". ${ }^{2}$

The hierarchy of different central and local institutions and offices of the Cossack State reflected the order of their public legal functions. Among these functions, the judicial and administrative ones were prioritized Their amount was the basic factor defining the place of an official or an institution under his control in the hierarchy. The hetman as an institution affected this order as well, which is especially evident during some short periods in the eighteenth century when it was eliminated. The osavul office had constantly been under the direct subordination to the hetman's will which positioned general osavul among the senior officers of the highest level and the courtiers of the closest circle; yet in the absence of hetman osavuls were primarily taking care of what made their public legal functions - namely, audition and army management.

The assumed "vagueness" and the supposed "inferiority" of the office of osavul in the hierarchy of cossack senior officers occurred as the consequence of its double nature. These people were both the public officials and the private servants of the commander. This is why the evolution of the osavul office seemed contradictory and irrational to historians. The Cossack State was developing on the base of a military system, and so osavuls were gaining more and more public functions. However, they continue to represent the person and the interests of their direct superior and patron - hetman - and act in the field of his personal interests. Probably, this is one of the remnants of the oriental backgrounds of the osavul institution since the respective officers in the Turkic nomadic systems had the same status in the hierarchy and relations with the rulers.

Peer-review: Externally peer-reviewed.

Conflict of Interest: The author has no conflict of interest to declare.

Grant Support: The author declared that this study has received no financial support.

Hakem Değerlendirmesi: Dış bağımsız.

Çıkar Çatışması: Yazar çıkar çatışması bildirmemiştir.

Finansal Destek: Yazar bu çalışma için finansal destek almadığını beyan etmiştir.

70 Horobec'Viktor, “Vsyakie polkovye uryady”. Polkova starshyna Het'manatu yak vladnyj instytut i socialna hrupa”, p.21.

71 Vijs'kovi kampanii doby hetmana Ivana Mazepy v dokumentah, upor. S.Pavlenko, Kyiv, 2009, p. 924-925, 953, 956.

72 Lazarevskij Aleksandr, Lokhvickij istoricheskij sbornik, Kiev, 1906, p.284. 


\section{Bibliography}

Apanovych Olena, Zbrojni syly Ukrainy pershoyi polovyny XVIII st., Kyiv, 1969.

Akty, otnosiashiesia k istorii Yugo-Zapadnoj Rossii (AYZR), Sankt-Peterburg 1861, t. III.

AYZR, Sankt-Peterburg, 1861, t.III

AYZR, Sankt-Peterburg, 1863, t.IV.

AYZR, Sankt-Peterburg, 1869, t.VI.

AYZR, Sankt-Peterburg, 1877, t.IX.

Andrievskij Aleksandr, “Kievskie smuty serediny proshlogo stoletia”, Kievskaja Starina,1886, №12, p.664-708.

Arkhiv Yugo-Zapadnoj Rossii, Kiev, 1872, Ch.1, t.V.

Babkova Nataliya, "Instytut osavuliv v ukrayins'komu kozactvi XVI - XVIII st.", Hileya: Naukovyj visnyk, 2015, v.96, p.11-14.

Cherkas Borys, “Kozac'ke vijs'ko do seredyny XVII st.", Istoriya ukrayins'koho kozactva: Narysy v 2 tt., Kyiv, 2006, t.I, p.472-484.

Dyadychenko Vadym, Narysy suspil'no-politychnoi istoriyi Livoberezhnoi Ukrayiny kincya XVII - pochatku XVIII st., Kyiv, 1959.

Dyadychenko Vadym, “Ukraynskoe kazackoe vojsko v konce XVII - nachale XVIII vv.", Poltava: K250-letyyu Poltavskoho srazhenyya, Moskva, 1959, p.246-268.

Dzherela z istoriyi Nacional'no-vyzvol'noyi vijny ukrayins'koho narodu 1648-1658 rr. /Upor.Yu.Mycyk, Kyiv, 2015, t.IV.

Dziubiński Andrzej, “Poturczeńcy polscy. Przyczynek do historii nawróceń na islam w XVI-XVIII w.”, Kwartalnik Historyczny, 1995, Nr.102/1, s.19-37.

Gliwa Andrzej, “O woskowości tatarskiej w epoce nowożytnej i oddziaływaniu koczowników na osiadłe spoleczności Rzeczypospolitej”, Spoleczeństwo Staropolskie, 2015, t.IV, s.89-133.

Góralski Zbigniew, Encyklopedia urzędów i godności w dawnej Polsce, Warszawa, 2000.

Halenko Oleksandr, "Konstytucijni idei Pylypa Orlyka z perspektyvy stepovyh vytokiv politychnoi tradycii ukrayins'koho kozactva", Pylyp Orlyk: zhyttia, polityka, teksty: Materialy Mizhnarodnoi naukovoi konferencii «Ad fontes» do 300-richchya Benders'koyi konstytuciyi 1710 r., Kyiv, 2001, p.224-233.

Halenko Oleksandr, "Luk ta rushnycia v lycars'kij symvolici ukrayins'koho kozactva: paradoksy kozac'koyi ideolohii ta problema shidnoho vplyvu”, Mediaevalia Ucrainica: Mental'nis't ta istoria idej, Kyiv, 1998, t.V, p.93-110.

Heneral'noe sledstvie o maetnostyakh Nezhynskoho polka 1729-1730 hh., Chernyhov, 1901

Horobec'Viktor, “Vsyakie polkovye uryady”. Polkova starshyna Het'manatu yak vladnyj instytut i socialna hrupa", Socium. Al'manah social'noyi istoriyi, 2017, v.13-14, p. 11-40.

Horobec'Viktor. “Kozac'kyj Het'manat u social'nij strukturi Rechi Pospolytoi: proekt ustroyevoyi modeli het'mana Pavla Teteri z roku 1664", Moloda naciya, 2000, №1, p. 40-61.

Horobec'Viktor, Politychnyj ustrij ukrayins'kyh zemel' druhoyi polovyny XVII - XVIII stolit', Kyiv, 2000.

Hrybovs'kyj Vladyslav, “Vijs'kova systema Nohajs'koi ordy ta yiyi restytuty u prychornomors'kyh nohajciv”, Humanitarnyj zhurnal, 2012, № 2-3, p.75-90.

Hrybovs'kyj Vladyslav, “Zaporoz'ke kozactvo i cholovichi soyuzy Kavkazu ta Central'noyi Aziyi v komparatyvnij perspektyvi", Hileya: naukovyj visnyk, 2011, v.52, p. 116-130. 
Hrybovs'kyj Vladyslav, “Socyal'naia typolohia kazach'yh soobshestv”, Kazachestvo v tyurkskom y slavyanskom myrah: Kollektyvnaya monohrafyya, Instytut arheolohii im.A.Halikova AN RT, Kazan', 2018, p. 94-172.

Istochniki malorossyjskoj istorii, Moskva, 1855, t.I

Kazimirov Dmytro, “Maetnosti chernihivs'koho polkovoho osavula Vasylia Pavlovs'koho u Mens'kij sotni", Siveryans'kyj litopys, 2016, № 1, p. 97-106.

Khazanov Anatolii, "The Eurasion Steppe Nomads in World Military History", Nomad Aristocrats in a World of Empires, Ed.by J.Paul, Weisbaden, 2013, p. 187-207.

Kołodziejczyk Dariusz, "Permeable Frontiers: Contacts between Polish and Turkish-Tatar Elites in Early Modern Era", Foreign Drums Beating. Transnational Expierences in Early Modern Europe, Ed.by B.Forsen and M.Hakkarainen, Helsinki, 2017, p. 153-168.

Kryvosheya Volodymyr. Kozac'ka elita Het'manshhyny, Kyiv, 2008.

Kryvosheya Volodymyr, Kryvosheya Iryna, Kryvosheya Olena. Neuryadova starshyna Het'manshhyny, Kyiv: «Stylos», 2009.

Kushkumbaev Aibolat, Voennoe delo kazakhov v XVII - XVIII vekah, Almaty: Dajk Press, 2001.

Kushkumbaev Aibolat, Instytut oblavnykh oxot i voennoe delo kochevnikov Central'noj Azii. Sravnytel'noistorycheskoe issledovanie, Kokshetau, 2009.

Kushkumbaev Aibolat, „Kryl'evaja model' v voenno-politycheskoj orhanizacii imperii Dzhuchidov”, Voennoe delo ulusa Dzhuchi i ego naslednikov: Sbornik nauchnykh statej, otv.red.A.Kushkumbaev, Astana: Foliant, 2012, p. 109-164.

Kushkumbaev Aibolat, „Rol' peredovoho vojska v monhol'skoj taktycheskoj modeli vojny”, Vestnik Evrazyjskoho nacyonal'noho universyteta im.L.N.Humyleva, 2009, № 1(68), p. 129-135.

Kushkumbaev Aibolat, „Smotr vojsk i znachenie pekhoty v voennoj orhanizacii Zolotoj Ordy”, Vestnik Kazakhskoho nacyonal'nogo universyteta im. Al'-Faraby. Seria istoricheskaja, 2009, № 2(53), p. 32-37.

Kushkumbaev Aibolat, „Takticheskoe postroenie vojsk v monhol'skuju epokhu”, Zolotoordynskaja cyvilizacia, 2014, № 7, p. 252-279.

Lazarevskij Aleksandr, Lokhvickij istoricheskij sbornik, Kiev, 1906.

Litopys Samovydcia, upor.J.Dzyra, Kyiv: Naukowa dumka, 1971.

Lomykovskyj Vasylij, “Slovar' malorusskoj stariny”, Kievskaja Starina, 1894, №7, p.10-16.

Lysty Ivana Mazepy, upor. V.Stanislavs'kyj, Kyiv, 2010, t.II.

„Malorossijskie chiny i dolzhnosti i oklad ikh soderzhanija”, Kievskaja Starina, 1883, № 6.

Manz Beatrice Forbes, "Nomads and Regional Armies in the Middle East", Nomadic Military Power in Iran and Adjacent Areas in the Islamic Period/Ed. by K.Franz and W. Holzwarth, Nomaden und Sesshafte 17. Wiesbaden: Reichert, 2013, p. 1-27.

Medveds'kyj Vladyslav, “Heneral'nyj osavul Yakiv Yakubovych ta joho vijskova diyal'nist”, Materialy XII mizhnarodnoyi mizhdyscyplinarnoyi naukovoyi konferenciyi studentiv, aspirantiv ta molodyx vchenyx "Shevchenkivs"ka vesna 2015: Istoriya», Kyiv, 2015, p. 290-293.

Medveds'kyj Vladyslav, “Diyal'nist' uryadu heneral'noho osavula za het'mana Bohdana Khmel'nyc'koho”, Dni nauky istorychnoho fakul'tetu, prysvyacheni 180-richchyu zasnuvannya Kyyivs'koho universytetu, Kyiv, 2014, p. 64-68.

Medveds'kyj Vladyslav, “Instytut heneral'nyh osavuliv u Het'manshhyni v seredyni XVII - kinci XVIII st.”, Materialy XII mizhnarodnoyi mizhdyscyplinarnoyi naukovoyi konferenciyi studentiv, aspirantiv ta molodyx vchenyx «Shevchenkivs"ka vesna 2014: Istoriya», Kyiv, 2014, p. 104-107.

Modzalevskyi Vadym, Malorossyjskyj rodoslovnik, Kiev, 1910, t.II. 
Nacional'na Biblioteka Ukrainy imeni V.Vernads'koho, Instytut Rukopysu (Kyiv, Ukraine) (NBUV. IR), Fond I, sprava 55453

NBUV. IR, Fond I, sprava 55454.

NBUV. IR, Fond I, sprava 55827.

NBUV. IR, Fond I, sprava 59060.

NBUV. IR, Fond II, sprava 15422.

Okynshevych Lev, "Heneral'na starshyna na Livoberezhnij Ukraini XVII - XVIII vv.", Praci komisii dlia vyuchuvannia zahidno-rus'koho ta vkrayins'koho prava, Kyiv, 1926, v.2.

Okynshevych Lev, "Central'ni ustanovy Ukrainy-Het'manshyny XVII - XVIII st. Ch.2: Rada starshyn”, Praci komisii dlia vyuchuvannia zahidno-rus'koho ta vkrayins'koho prava, Kyiv, 1930, v. 8.

Paul Jurgen, "The State and the Military - a Nomadic Perspective”, Militär und Staatlichkeit. Beiträge des Kolloquiums am 29. und 30.04.2002, Hg.I.Schneider, Halle, 2003 (Orientwissenschaftliche Hefte 12; Mitteilungen des SFB „Differenz und Integration“ 5), p. 25-68.

Pavlenko Serhii, Otochennia het'mana Mazepy: soratnyky ta prybichnyky, Kyiv, 2004.

Poltavs'ka mis'ka knyha (1668-1740), upor.V.Rynsevych, Kyiv, 2016.

Prava, za iakymy sudyt'sia malorosijs'kyj narod. 1743, Kyiv, 1997.

Putro Oleksii, “Ukrayins'ke kozac'ke vijs'ko”, Kyivs'ka starovyna, 1997, № 6, p.3-33.

Pylypenko Volodymyr, "Skhidne oblychchya kozaka Mamaya”, Visnyk Chernihivs'koho nacional'noho pedahohichnoho universytetu. Seriya: Istorychni nauky, 2015, v.134, p. 18-23.

Rossyjskyj Gosudarstvennyi Arkhiv Drevnikh Aktov (Moscow, Russia), Fond 13, opys 1, delo 40.

Sen'Dmitrij, “Kazach'e naselenie Krymskoho hanstva: maloizuchennye aspekty rasselenija (konec XVII XVIII vv.)", Vspomohatel'nye istorycheskye dyscyplyny v sovremennom nauchnom znanii: Materyaly XXXI Mezhdunarodnoj nauchnoj konferencii. Moskva, 12-14 aprelia 2018 h., Moskva: Institut vseobshhej istorii RAN, 2018, p. 327-330.

Serhijchuk Volodymyr, Armiya Bohdana Khmel'nyc'koho, Kyiv, 1996.

Sherer Zhan-Benua, Litopys Malorosiyi, abo Istoriya kozakiv-zaporozhciv, per.z fr. V.Koptilov, Kyiv, 1994.

Slabchenko Mikhail, Malorusskij polk v admynystrativnom otnoshenii. Istoriko-yuridicheskij ocherk, Odessa, 1909.

Sokyrko Oleksii, „Malorosijs'ka rehuliarna rota 1733-1739 rr.”, Kyivs'ka starovyna, 2010, № 5, p. 17-28.

Sokyrko Oleksii, “Ukrayins'ke vijs'ko Kozac'koyi doby”, Istoriya ukrayins'koho vijs'ka, Kharkiv, 2016, p. 203-234.

Stanislavs'kii V'iacheslav, "Vijs'ko Zaporoz'ke u voyennomu protystoyanni j myrnyh perehovorah z Kryms'kym hanstvom u svitli novyh danyh z dokumentiv Ivana Mazepy 1691-1694 rr.", Het'man Ivan Mazepa: postat', otochennya, epoha. Zbirnyk naukovyh prac', Kyiv, 2008, p. 185-208.

Storozhenko Ivan, Bohdan Khmel'nyc'kyi i voyenne mystectvo u Vyzvol'nij vijni ukrayins'koho narodu seredyny XVII stolittya, Dnipropetrovs'k, 1996, kn.l.

Ukraina-Shveciya: Na perehrestyah istoriyi (XVII - XVIII st.). Kataloh mizhnarodnoyi vystavky, Kyiv, 2008. Vijs'kovi kampanii doby hetmana Ivana Mazepy v dokumentah, upor. S.Pavlenko, Kyiv, 2009.

Vlastnye instituty i dolzhnosti v Evrope $v$ Srednie veka y rannee Novoe vremya, otv.red.T.Husarova, Moskva: KDU, 2011.

Yavornyc'kyj Dmytro, Istoriya zaporiz'kyh kozakiv /Per.z ros.I.Svarnyka, L'viv: Svit, 1990, t.I.

Zaruba Viktor, Ukrayins'ke kozac'ke vijs'ko v rosijs'ko-turec'kyh vijnah ostann'oyi chverti XVII stolittya, Dnipropetrovs'k, 2003. 